\title{
The influence of the tasks characteristics in physical performance and psychosocial aspects of workers
}

\author{
Rosimeire Simprini Padula ${ }^{a^{*}}$; Juliana Neves Rosina ${ }^{\mathrm{b}}$; Cristina Maria Nunes Cabral ${ }^{\mathrm{a}}$; Sandra Maria \\ Sbeghen Ferreira de Freitas ${ }^{\mathrm{a}}$; Luciana Dias Chiavegato ${ }^{\mathrm{a}}$ \\ ${ }^{a}$ Masters in Physical Therapy Program, Universidade Cidade de São Paulo, R. Cesário Galeno, 448, São Paulo, \\ Brazil \\ ${ }^{b}$ School of Physical Therapy, Universidade Cidade de São Paulo, R. Cesário Galeno, 448, São Paulo, Brazil
}

\begin{abstract}
The work and life conditions have influence on the health and life quality of workers. Physically active persons can demonstrate a life style that are and affect the physical performance, psychosocial aspects and work capacity. The purpose of this study was to investigate the physical activity level and work capacity in different tasks characteristics, one with more physical exertion and other with more cognitive exertion. A total of 193 workers from an institution of higher education and 457 workers from a metallurgical industry participated in the current study. All participants completed the International Physical Activity Questionnaire (IPAQ-short) and Work Ability Index (WAI). The results indicated that both groups were classified as having high level of physical activity while only few of them were considered sedentary (less than $27 \%$ ). However, the group of metallurgical workers had greater indices (82\%) than the workers from higher education institution (74\%). Overall, the workers reported their work ability as moderate to excellent, suggesting that overall they are satisfied with their working and health conditions. It can be concluded that even though workers performed tasks with different demands (cognitive versus physical), they demonstrated similar level of physical activity as well as work ability.
\end{abstract}

Keywords: Occupational Health; Physical Therapy; Work Ability

\section{Introduction}

The job held by an individual, regardless of location and type of activity, generates various demands and stress factors that need to be balanced with their personal capacities to avoid physical or mental effort ${ }^{[5]}$. The knowledge of the work demands could contribute in the execution of ergonomic adjustments to improve work processes, and therefore the worker's health ${ }^{[2]}$. The conditions of working environment are related mostly to the profession pursued by the approach adopted by the worker and the way he is both physically and psychologically ${ }^{[3-7]}$. The physical activity level of each individual can differentiate between populations, depending on social class and education ${ }^{[11]}$. The regular practice of some physical activity could be one way to improve quality of life and health of an individual ${ }^{[4-6]}$.Many benefits achieved with it can directly affect the individual's daily life, improving not only their performance but also their functional well-being and ability and willingness to perform various tasks, personal and professional ${ }^{[4-11]}$. Indeed, active individuals were considered as having lower risk of developing diseases associated with sedentary lifestyle, characteristics professional and personal ${ }^{[6]}$. Therefore, the purpose of the current study was to assess the level of physical activity and work ability of individuals with different work functions and verify whether there is an association between them.

\footnotetext{
*Corresponding author. E-mail: rosipadula@gmail.com.
} 


\section{Material and Methods}

\subsection{Design}

This cross-sectional study was qualitative and included 193 workers from an institution of higher education and 458 workers from a metallurgical industry of both gender.

The workers answered a questionnaire with personal data, Work Ability Index (WAI) ${ }^{[8]}$ and International Physical Activity Questionnaire (IPAQ-short) ${ }^{[10-13]}$.The questionnaires were applied in a private room, for groups of up to twenty workers. Participants received information about the study and signed an informed consent prior their participation.

Workers who could not be present in the room to complete the questionnaires received, in a sealed envelope, the containing information about the study, the informed consent and the questionnaires. They were asked to read the description about the study, sign the informed consent and complete the questionnaires before returning the material to the researchers.

\subsection{Characteristics of the Groups}

\subsubsection{Higher Education}

These workers were from a private institution of higher education located in São Paulo city. They reported that they usually go to work using a public transportation such as subway, train or bus. Participants of this group were involved in their studies/education for four or five hours and worked eight hours per day. The most common activity performed by the participants was related to administrative sector. About education 5.8\% were graduated and 7.0\% had enrolled in other courses after their graduation.

\subsubsection{Metallurgical Industry}

The company was located in Guarulhos and over $80 \%$ of workers were in the productive sector and performed tasks that required the use of force, load handling, production control and quality. Most workers lived near the company and went to work by bicycle or walking. Public transportation (bus) was also provided by the company. Regarding to education, the maximum level obtained by the workers was high school (about $0.3 \%$ ) while most of the workers were fundamental school $(31.5 \%)$

\subsection{International Physical Activity Questionnaire (IPAQ)}

The short version of IPAQ includes 8 open questions and information to estimate the time spent, per week, in different physical activities (walking and moderate and intense physical exertion) and physical inactivity (sitting position). It is an instrument designed to classify the physical activity level of the participants. Participant was considered physically active if he/she performed at least 150 minutes of physical activity for five or more days per week and sedentary if the participant performed less than 10 minutes of daily physical activity or less than 150 minutes per week of physical activity ${ }^{[1]}$.

\subsection{Work Ability Index}

The Work Ability Index (WAI) is an instrument developed by the Finnish Institute of Occupational Health to evaluate how the worker is able to perform their work now at present and in the future. The conclusion of the evaluation is made based on answers to a series of questions, considering the physical and mental demands of work, health status and resources of the worker. The final score ranges from 7 to 49 points demonstrating the worker's own perception about his ability to work.

It consists of seven items; each comprising one, two or three questions with each answer credited with a score. The score for item 2 (work ability in relation to the demands of work) is weighted according to the work which is primarily physical, mental or both depending on the function of the individual. The final score of Work Ability Index is categorized in: poor (7-27 points), moderate (28-36 points), good (37-43 points) and excellent (44-49 points).

\subsection{Data Analysis}

The Statistical Package for Social Sciences (SPSS) software version 17.0 was used for statistical analysis, and significance was set at $5 \%(P<0.05)$. Descriptive statistical analysis was applied (mean, SD) and association between dependent variables (Work abitity index and level physical activity - IPAQ) was investigated by means of Chi-Square test.

\subsection{Ethical aspects}

All participants were informed about the objectives and procedures of the study and were invited to participate by signing an informed consent form previously approved by the local ethics committee (Proc. $\mathrm{N}^{\circ}$ 0048.1.186.000-10). 


\section{Results}

The group of workers from the institution of higher education was composed by 193 workers (about 54\% of the total invited workers). All invited workers from metallurgical industry participated in the study. The group of higher education and metallurgical industry had mean age of $30.26 \pm 8.70$ years and 31.42 \pm 10.48 years, respectively. The male population of the metallurgical industry group is greater than the higher education group that has a predominance of female workers (Table 1).

Table 1

Classification by gender per group.

\begin{tabular}{lccc}
\hline \multicolumn{1}{c}{ Groups } & Gender & N & $\%$ \\
\hline Higher & Female & 124 & 64.2 \\
Education & Male & 69 & 35.7 \\
& Total & 193 & 100.0 \\
\hline $\begin{array}{l}\text { Metallurgical } \\
\text { Industry }\end{array}$ & Female & 101 & 22.0 \\
& Male & 357 & 18.0 \\
& Total & 458 & 100.0 \\
\hline
\end{tabular}

For both groups, most of participants was classified as physically active, above 150 minutes per week.
But the metallurgical company group had a higher rate of active individuals, about $82.3 \%$ (Table 2).

Regarding to the WAI results, most workers found rates of capacity to work between good and excellent for higher education group; and moderate, good and excellent for metallurgical industry group (Table 2). In addition, more workers from metallurgical industry group reported poor work ability compared to higher education group. These findings were revealed independent of the physical activity level of the workers. Indeed, it was not found an association between the work ability and physical activity level for higher education group $(P=0.44)$ and metallurgical industry group $(P=0.21)$.

\section{Discussion}

The percentage of participants who achieved the current recommended physical activity level for health promotion was $73.6 \%$ and $82.3 \%$, respectively, for the institution of higher education and metallurgical company. These indices are higher than the rate of

Table 2

Work Ability Index per group.

\begin{tabular}{|c|c|c|c|c|c|c|c|}
\hline \multirow[b]{2}{*}{ Groups } & \multirow[b]{2}{*}{ Active } & & \multicolumn{4}{|c|}{ Categories (WAI) } & \multirow[b]{2}{*}{ Total } \\
\hline & & & Excellent & Good & Moderate & Poor & \\
\hline \multirow[t]{6}{*}{ Higher Education } & Yes & Count & 47 & 65 & 28 & 2 & 142 \\
\hline & & $\%$ of Total & $24.4 \%$ & $33.7 \%$ & $14.5 \%$ & $1.0 \%$ & $73.6 \%$ \\
\hline & No & Count & 18 & 27 & 5 & 1 & 51 \\
\hline & & $\%$ of Total & $9.3 \%$ & $14 \%$ & $2.6 \%$ & $0.5 \%$ & $26.4 \%$ \\
\hline & Total & Count & 65 & 92 & 33 & 3 & 193 \\
\hline & & $\%$ of Total & $33.7 \%$ & $47.7 \%$ & $17.1 \%$ & $1.6 \%$ & $100.0 \%$ \\
\hline \multirow{6}{*}{$\begin{array}{l}\text { Metallurgical } \\
\text { Industry }\end{array}$} & Yes & Count & 42 & 233 & 94 & 8 & 377 \\
\hline & & $\%$ of Total & $9.2 \%$ & $50.9 \%$ & $20.5 \%$ & $1.7 \%$ & $82.3 \%$ \\
\hline & No & Count & 6 & 44 & 29 & 2 & 81 \\
\hline & & $\%$ of Total & $1.3 \%$ & $9.6 \%$ & $6.3 \%$ & $.4 \%$ & $17.7 \%$ \\
\hline & Total & Count & 48 & 277 & 123 & 10 & 458 \\
\hline & & $\%$ of Total & $10.5 \%$ & $60.5 \%$ & $26.9 \%$ & $2.2 \%$ & $100.0 \%$ \\
\hline
\end{tabular}


active individuals in the State of São Paulo (approximately $46 \%$ of the participants ${ }^{[10]}$. The present study suggested that even though participants had different functions in their work, their physical activity levels were very similar ${ }^{[9]}$. In addition, although the workers from the institution of higher education showed their own perception for work ability as good and excellent and the workers from metallurgical industry reported it as moderate to good, both groups seemed to be satisfied with their ability to work. Some factors such as gender, aging, activities characteristics and stress could have influenced the work ability report ${ }^{[3-15]}$. However, the aging are similar and for gender case it is more common the female group be considered worst $^{[12-14]}$. One limitation of the study was that individuals had difficulty understanding some questions, and to calculate the time spending on different physical activities. Furthermore, we believe that these values may be overestimated, particularly, in workers of the higher education institution as they have greater cognitive demands in their physical activities and could have more opportunities to regularly participate in physical activities programs ${ }^{[4]}$. However, the distinct groups of participants overall rated their ability to work as good, which shows that they saw themselves with favorable work ability.

\section{Conclusion}

It could be concluded that workers had good levels of physical activity and work ability, regardless of their work demands. The tasks characteristics seemed to have some influence only in the worker's perception for work ability for the metallurgical industry group which it could be related to more physical efforts performed in their tasks.

\section{Acknowledgements}

This study was supported by CNPq.

\section{References}

[1] Alves JGB, Siqueira FV, Figueiro JN, Facchini LA, Silveira DS, Piccini RX, Tomasi E, Thumé E, Hallal PC. Prevalência de adultos e idosos insuficientemente ativos moradores em áreas de unidades básicas de saúde com e sem Programa Saúde da Família em Pernambuco, Brasil. Cad. Saúde Pública [online]. 2010; 26 (3) :543-556.
[2] Bellusci, SM, Fischer FM. Envelhecimento funcional condições de trabalho em servidores forenses. Rev. Saúde Pública. 1999; 33 (6): 602-611.

[3] Camerino D, Conway PM, Van der Heijden BIJM, EstrynBéhar M, Costa G, Hasselhorn HM. Age-dependent relationships between work ability, thinking of quitting the job, and actual leaving among Italian nurses: a longitudinal study. Int J Nurs Stud. 2008;45:1645-59.

[4] Hallal, PC, Dumith SC, Bastos JP, Reichert, FF; Siqueira FV; Azevedo MR. Evolução da pesquisa epidemiológica em atividade física no Brasil: revisão sistemática. Rev Saúde Pública 2007;41(3):453-60.

[5] Lacaz FAC, Qualidade de vida no trabalho e saúde/doença. Rev Ciência e Saúde Coletiva. 2000; 5(1): 151-161.

[6] Laporte RE, Montoye HJ, Caspersen CJ. Assessment of physical activity in epidemiologic research: problems and prospects . 1985; 100 (2): 127.

[7] Martinez CM, Latorre MRDO. Saúde e capacidade para o trabalho em trabalhadores de área administrativa. Rev Saúde Pública 2006;40(5):851-859.

[8] Martinez CM, Latorre MRDO, Fischer FM. Validade e confiabilidade da versão brasileira do Índice de Capacidade para o Trabalho. Rev. Saúde Pública. 2009; 43(3): 525-532

[9] Martinez MC, Latorre MRDO, Fischer FM. Capacidade para o trabalho: revisão de literatura. Ciênc. saúde coletiva. 2010; 15, suppl.1: 1553-1561.

[10] Matsudo S, Araujo T, Matsudo V, Andrade D, Andrade E; Oliveira LC; Braggion G. Questionario Internacional de Atividade Fisica (IPAQ): Estudo de Validade e Reprodutibilidade No Brasil. Atividade Fisica \& Saúde. 2001; 6 (2):5-18.

[11] Matsudo SM, Matsudo VR, Araújo T, Andrade D, Andrade E, Oliveira L, Braggion G. Nível de atividade física da população do Estado de São Paulo: análise de acordo com o gênero, idade, nível socioeconômico, distribuição geográfica e de conhecimento. Rev. Bras. Ciên. e Mov. Brasília. 2002; 10(4): 41-50.

[12] Monteiro MS, Fischer FM; Barros MD; Rodrigues, CM Gender and work ability among public workers: a crosssectional study.2007; Online Brazilian Journal of Nursing; 6:239.

[13] Pardini, R.; Matsudo, S.M.; Araújo, T.; Matsudo, V.; An drade, E.; Braggion, G.; Andrade, D.; Oliveira, L.; Figueira Jr., A.; Raso, V. Validation of the International Physical Activity Questionaire (IPAQ-version 6): pilot study in Brazilian young adults. Rev. Bras. Ciên. e Mov. 2001; 9(3): 45-51.

[14] Padula RS; Valente LSS; Pereira AAGP; Oliveira CCP; Sperling MPR;ChiavegatoL. Avaliação da capacidade para o trabalho e da aptidão cardiorrespiratória de trabalhadores saudáveis. ConScientiae Saúde, 2011;10(2):285-291.

[15] Sluiter JK. High-demand jobs: Age-related diversity in work ability? Applied Ergonomics.2006; 37:429-440. 